\title{
THE BRYOPHYTE FLORA OF THE PARK OF MÁTRAI GYÓGYINTÉZET SANATORIUM (NE HUNGARY)
}

\author{
Péter Szúcs ${ }^{1}$, Gergely Baranyi ${ }^{2}$ \& Gabriella Fintha ${ }^{2}$
}

${ }^{1}$ Eszterházy Károly University, Institute of Biology, Department of Botany and Plant Physiology, H-3300 Eger, Leányka str. 6, Hungary; ${ }^{2}$ Eszterházy Károly University,

Faculty of Natural Sciences, H-3300 Eger, Leányka str. 6, Hungary;

*E-mail: szucs.peter@uni-eszterhazy.hu

\begin{abstract}
The aim of this study was to explore the bryophyte diversity in the garden of Mátrai Gyógyintézet Sanatorium. In the investigated area 65 bryophytes were found, 3 liverworts and 62 mosses. Some near threatened taxa according to the Hungarian Red List were detected in the territory: Brachythecium glareosum, Cirriphyllum piliferum, Orthotrichum pumilum, Rhynchostegiella tenella and Syntrichia latifolia. The recent record of Syntrichia latifolia is the second in the North Hungarian Mountains, and the first in Mátra Mountains.
\end{abstract}

Keywords: bryophytes, high altitude, Syntrichia latifolia, semi-natural habitats

\section{INTRODUCTION}

Parks and large public gardens can be interesting hot spots of biodiversity, since they are places where the human endeavor to form a landscape meets the tendency of nature to conquer back any area where the anthropogenic impact is diminished (Nielsen et al. 2014).

During the last decades, the bryophyte floras of several Central and Eastern European parks and gardens have been studied, for example Warsaw, Łódź and other Polish cities (Fudali 2006, Wolski et al. 2012), Bucharest (Gomoiu and Ștefâțnuţ 2008), Vel'ký Krtíš (Mišíková et al. 2007), Olomouc (Vejmelková 2014), Bratislava (Godovičová and Mišíková 2017), Martonvásár (Nagy et al. 2016), and Almásfüzitő (Szűcs et al. 2017). The main objective of the present study was the examination of the bryophyte diversity of the garden of Mátrai Gyógyintézet Sanatorium. Such a study seemed particularly promising since the area is situated in a 
mountain area, at high elevation, thus exceptional compared with similar studies (e.g. manor park in Martonvásár (Nagy et al. 2016)) which refer to lowland areas.

\section{MATERIAL AND METHODS}

The nomenclature follows Király (2009) for vascular plants, Söderström et al. (2016) for liverworts, Hill et al. (2006) for mosses. In order to characterise the conservation and indicator status of taxa the Hungarian Red List was used (Papp et al. 2010).

Site details descriptions (in the Appendix) include data in the following order: habitat, GPS-coordinates, date of collection. The identifiers of the quadrates according to the Central European Flora Mapping System were indicated in sqaure brackets (Király et al. 2003). Each collection point belongs to the 8185.1 square. Specimens were collected on 22.09.2018 and 03.10.2018, respectively, as indicated in the Appendix.

Collected specimens are stored at the Cryptogamic Herbarium of the Department of Botany and Plant Physiology at the Eszterházy Károly University, Eger (EGR).

\section{Study area}

The study area (14 ha), between 650 and 700 meters above the sea level, is situated within Észak Magyarországi Középhegység, (North Hungarian Mountains), in Mátravidék, Magas Mátra, the highest of the Hungarian mountain ranges. It is located in Heves county, within the administrative unit of Mátraháza (Gyöngyös) (Dövényi 2010). We can mainly find volcanic rock, mostly andesite and andesite-liparite tuff. The area involves the highest parts of Mátra Mts with relatively high amount of precipitation, resulting in strong soil leaching. Soils, mostly lava clay, usually have medium water absorption, low water conductivity, and high water retention. Among the soil types, the most common is the brownforest soil with clay leaching, with various depths and varying bedrock (Baráz et al. 2000). The climate of the area is cool and wet. The annual number of sunny hours is 2000 at the highest peaks, and 1900 lower. During summer the number of sunny hours is 740-750, and during winter 250 hours at the highest points. The annual average temperature is $6-8^{\circ} \mathrm{C}$. (Dövényi 2010). The southeastern side of the hospital garden is affected by the Bene-stream in a short distance. The flora of the Mátra is rich in mountain elements. The distribution of the vegetation is dependent on the bedrock and the soil type on it. Montane species of vascular plants appear 
in the submontane beech forests (Polystichum aculeatum, Lunaria rediviva, Daphne mezereum) (Baráz et al. 2000).

The hospital (and probably its own garden) was established between 1927 and 1931 in a former meadow called Nagy Somorrét. In addition to the main building, there were 7 smaller buildings in the area including laundry, garage, residential building, kindergarden and gate. Because of the isolation of the site self-sufficiency was attempted, with own water supply and sewage treatment systems, laundry, bakeries, horticulture, pig farm, maintenance workshops. The staff lived in the premises (Padányi 1933). The current regular garden care works include mowing lawns and gathering leaves. The bryofloristic exploration was carried out by the authors in the fenced-in area of the hospital garden, exploring the following micro-habitats: road bridges, road edges, concrete and stone constructions (Figure 2), rooftops, mowed lawns (Figure 3), creeks, rock gardens, bark of trees and soil.

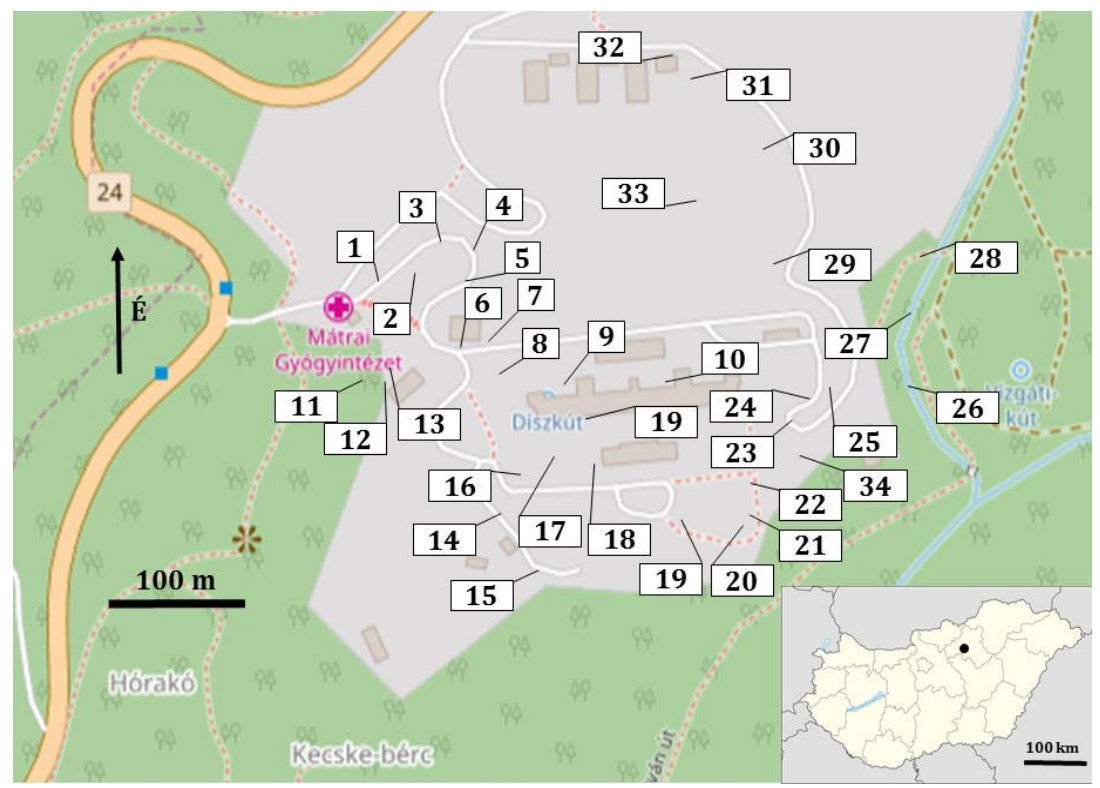

Figure 1. Map of the park of the Mátrai Gyógyintézet Sanatorium and the collecting points (C) OpenStreetMap contributors) 


\section{RESULTS AND DISCUSSION}

\section{List of species}

Numbers refer to sites (Figure 1) listed in the Appendix. The substrates given after a colon refer to all listed sites.

Marchantiophyta

Frullania dilatata (L.) Dumort. - 11: bark of Quercus petraea Plagiochila porelloides (Torr. ex Nees) Lindenb. - 4, 7: soil Metzgeria furcata (L.) Corda - 26: bark of Fagus sylvatica

Bryophyta

Amblystegium serpens (Hedw.) Schimp. - 17: root of Carpinus betulus

Atrichum undulatum (Hedw.) P.Beauv. - 3, 5, 7: soil

Barbula unguiculata Hedw. - 1, 7, 14, 18: soil

Brachytheciastrum velutinum (Hedw.) Ignatov \& Huttunen - 4, 28: soil

Brachythecium glareosum (Bruch ex Spruce) Schimp. - 7, 9: soil;

10: artifical stone

Brachythecium rutabulum (Hedw.) Schimp. - 3, 5, 18, 28: soil

Brachythecium rivulare Schimp. - 27: concrete

Bryum argenteum Hedw. - 1, 14, 18: soil; 32: mortar debris

Bryum caespiticium Hedw. - 32: mortar debris

Bryum moravicum Podp. - 17: root of Carpinus betulus

Calliergonella cuspidata (Hedw.) Loeske - 9: soil

Calliergonella lindbergii (Mitt.) Hedenäs - 7, 24: soil

Campyliadelphus chrysophyllus (Brid.) R.S.Chopra - 7: soil

Ceratodon purpureus (Hedw.) Brid. - 8: asphalt roofing felt; 18:

soil

Cirriphyllum piliferum (Hedw.) Grout - 7: soil

Cirriphyllum crassinervium (Taylor) Loeske \& M.Fleisch. - 7: soil

Climacium dendroides (Hedw.) F.Weber \& D.Mohr - 2, 3, 5: soil

Dicranella heteromalla (Hedw.) Schimp. - 4, 7: soil

Dicranella varia (Hedw.) Schimp. - 14: soil

Drepanocladus aduncus (Hedw.) Warnst. - 19: artifical stone

Dicranum montanum Hedw. - 34: decayed wood 
Dicranum scoparium Hedw. - 34: decayed wood

Eurhynchium angustirete (Broth.) T.J.Kop. - 20, 21, 22, 29: soil

Fissidens taxifolius Hedw. - 28: soil

Grimmia muehlenbeckii Schimp. - 23: andesite stone

Grimmia pulvinata (Hedw.) Sm. - 13: artifical stone

Isothechium alopecuroides (Lam. ex Dubois) Isov. - 11: bark of

Quercus petraea

Homalia trichomanoides (Hedw.) Brid. - 12: stone

Homalothecium lutescens (Hedw.) H.Rob. - 25: soil

Homomallium incurvatum (Schrad. ex Brid.) Loeske - 25:

concrete

Hedwigia ciliata (Hedw.) P.Beauv. -8: asphalt roofing felt; 14, 16, 23: andesite rock

Hygroamblystegium tenax (Hedw.) Jenn. - 26: stone

Hypnum cupressiforme Hedw. - 25: concrete; 30: bark of Betula pendula

Orthotrichum affine Schrad. ex Brid. - 30: bark of Betula pendula

Orthotrichum anomalum Hedw. - 13, 19: artifical stone; 25 : concrete

Orthotrichum cupulatum Hoffm. ex Brid. - 13: artifical stone

Orthotrichum diaphanum Schrad. ex Brid. - 6, 16, 32: artifical stone

Orthotrichum pumilum Sw. ex anon. - 25: bark of Fraxinus

Oxyrrhynchium hians (Hedw.) Loeske - 2, 7, 17, 29: soil

Mnium marginatum (Dicks.) P.Beauv. - 7: soil

Plagiomnium affine (Blandow ex Funck) T.J.Kop. - 7, 24: soil

Plagiomnium cuspidatum (Hedw.) T.J.Kop. - 28: soil

Plagiomnium undulatum (Hedw.) T.J.Kop. - 9, 10: soil

Plagiothecium nemorale (Mitt.) A.Jaeger - 26: soil

Platygyrium repens (Brid.) Schimp. - 15: bark of Quercus petraea

Pleurozium schreberi (Willd. ex Brid.) Mitt. - 24: soil

Pohlia nutans (Hedw.) Lindb. - 34: decayed wood

Polytrichastrum formosum (Hedw.) G.L.Sm. - 3: soil

Polytrichum juniperinum Hedw. - 3: soil

Pseudoleskeella nervosa (Brid.) Nyholm - 11: bark of Quercus petraea

Pseudoscleropodium purum (Hedw.) M.Fleisch. - 20, 21, 33: soil

Pteryginandrum filiforme Hedw. - 26: bark of Fagus sylvatica

Pylaisia polyantha (Hedw.) Schimp. - 30: bark of Betula pendula Rhynchostegiella tenella (Dicks.) Limpr. - 22: shaded stone 
Rhytidiadelphus triquetrus (Hedw.) Warnst. - 21, 31: soil

Rhytidiadelphus squarrosus (Hedw.) Warnst. - 19, 20, 21, 22: soil

Rhizomnium punctatum (Hedw.) T.J.Kop. - 26, 27: soil

Syntrichia latifolia (Bruch ex Hartm.) Huebener - 13: artifical

stone

Syntrichia ruralis (Hedw.) F.Weber \& D.Mohr - 8: asphalt roofing

felt; 25: concrete

Syntrichia virescens (De Not.) Ochyra - 13: artifical stone

Thuidium assimile (Mitt.) A.Jaeger - 3, 7, 22, 29: soil

Tortula muralis Hedw. - 6, 13, 16, 19, 32: artifical stone, 25:

concrete

\section{Number of taxa, conservation status, indicator species}

According to the present study, 65 bryophytes were collected in the park of the Mátrai Gyógyintézet Sanatorium, including 3 liverworts and 62 mosses.

The authors found some mosses which are still not threatened, but need attention (LC-att) according to the Hungarian Bryophyte Red List (Papp et al. 2010) (e.g. Brachythecium rivulare, Climacium dendroides, Grimmia muehlenbeckii, Homalia trichomanoides, Hypnum lindbergii, Mnium marginatum, Orthotrichum cupulatum, Syntrichia virescens).

Near threatened species were as follows from the study area: Brachythecium glareosum, Cirriphyllum piliferum, Orthotrichum pumilum, Rhynchostegiella tenella and Syntrichia latifolia.

Some indicator species, which show a greater level of conservation value of the habitat, also occur in the park, e.g. Grimmia muehlenbeckii, Homalia trichomanoides, Mnium marginatum, Orthotrichum cupulatum, Orthotrichum pumilum and Rhynchostegiella tenella.

\section{Syntrichia latifolia}

Syntrichia latifolia is a temperate floral element with circumpolar distribution, which mainly occurs on roots and boles of Salix and Populus trees in Cental Europe, but has also been collected from anthropogenic substrate, for example concrete, bitumen and asphalt (Dierßen 2001, Düll 2010).

In Hungary, this moss has been found until recently only on the bark of trees or less often thatched roofs along the riparian zone of the rivers of Danube and Tisza in Hungary (Orbán and Vajda 1983). 
P. Erzberger detected the first record of this species growing on andesite rock in a colline area of Hungary (Cserhát Mts., Zsunyibrook) (Erzberger 2002). New interesting data from bark of Fagus sylvatica were published from Zala county (W Hungary), $300 \mathrm{~m}$ above sea level (Papp and Szurdoki 2018).

Our find is the first data from a mountain region, and the first published record from a man-made substrate (artifical stone) in Hungary (Figure 2). However, earlier in 2018 the species was found on concrete in the region of Zselic by K. Baráth and P. Erzberger in the village of Bárdudvarnok-Bánya in Somogy County (unpublished, P. Erzberger pers. comm.) On the other hand, our record represents the second locality to the North Hungarian Mountains, and the first to the Mátra Mts.

Acknowledgement - The authors would like to express their gratitude to Peter Erzberger and Andrea Sass-Gyarmati for their useful comments. The first author's research was supported by the grant EFOP-3.6.1-16-2016-00001 ("Complex improvement of research capacities and services at Eszterházy Károly University"). The authors are grateful to László Urbán (Mátrai Gyógyintézet Sanatorium) for making sample collection possible.

\section{REFERENCES}

Baráz, Cs., Dudás, Gy., Holló, S., Szuromi, L. \& VojtKó, A. (eds.) (2010). A Mátrai Tájvédelmi Körzet. Bükki Nemzeti Park Igazgatóság, Eger, 432 pp.

DövÉNYI, Z. (ed.) (2010). Magyarország kistájainak katasztere. MTA Földrajztudományi Kutatóintézet, Budapest, 824 pp.

DIERßEN, K. (2001). Distribution, ecological amplitude and phytosociological characterization of European bryophytes. Bryophytorum Bibliotheca 56: 1289.

DüLL, R. (2010). Autoekologie der Moose Mitteleuropas, manuscript, 289 pp.

ERzBERger, P. (2002). Minor contribution to the bryoflora of the Cserhát Mts. Studia botanica hungarica 33: 41-45.

FUDALI, E. (2006). Influence of city on the floristical and ecological diversity of bryophytes in parks and cemeteries. Biodiversity. Research and conservation 12: 131-137.

GodovičovÁ, K. \& MišíkovÁ, K. (2017). Epifytické machorasty urbánneho prostredia Bratislavy (Epiphytic bryophytes in the urban environment of Bratislava). Bryonora 59: $44-57$.

Gomolu, I. \& ȘTEFÂŢNUȚ S. (2008). Lichen and bryophytes as bioindicator of air pollution. In: CRACIUM I. (ed.) Species monitoring in the central parks of Bucharest. Universitatea din Bucureşti, Bucharest, pp. 14-25.

Hill, M.O., Bell, N., Bruggeman-Nannaenga, M.A., Brugues, M., Cano, M.J., Enroth, J., Flatberg, K.I., Frahm, J.P., Gallego, M.T., Gariletti, R., Guerra, J., Hedenäs, L., Holyoak, D.T., Hyvönen, J., Ignatov, M.S., Lara, F., Mazimpaka, V., Muñoz, J. \& 
SöDERSTRÖM, L. (2006). An annotated checklist of the mosses of Europe and Macaronesia. Journal of Bryology 28: 198-267.

https://doi.org/10.1179/174328206x119998

KirÁly, G., BAlogh, L., BARina, Z., BARTha, D., BAUER, N., Bodonczi, L., DANCZA, I., FARKAS, S., Galambos, I., Gulyás, G., Molnár, V. A., Nagy, J., Pifkó, D., Schmotzer, A., Somlyai, L., Szmorad, F., Vidéki, R., VojtKó, A., \& Zólyomi, Sz. (2003). A magyarországi flóratérképezés módszertani alapjai. Flora Pannonica 1: 3-20.

KIRÁLY, G. (ed.) (2009). Új magyar füvészkönyv (Magyarország hajtásos növényei, határozókulcsok). Aggteleki Nemzeti Park Igazgatóság, Jósvafő, 616 pp.

ORBÁN, S. \& VAJDA, L. (1983): Magyarország mohaflórájának kézikönyve. (Handbook of the Hungarian bryoflora). Akadémiai Kiadó, Budapest, 518 pp.

MišíkovÁ, K., Mıšı́, M. \& KubinSKÁ, A. (2007). Bryophytes of the forest park Hôrka (Vel'ký Krtíš town, Slovakia). Acta Botanica Universitatis Comenianae 43: 9-13.

NAGY, Z., MAJLÁTh, I., MolnÁR, M. \& ERZBERGER, P. (2016). A martonvásári kastélypark mohaflórája. (Bryofloristical study in the Brunszvik manor park in Martonvásár, Hungary). Kitaibelia 21(2): 198-206. https://doi.org/10.17542/kit.21.198

Nielsen, A.B., Bosch, M., MaruthaveEran, S. \& Bosch, C.K. (2014). Species richness in urban parks and its drivers: A review of empirical evidence. Urban Ecosystems 17(1): 305-327. https://doi.org/10.1007/s11252-013-0316-1

PADÁNYI, G.J. (1933). A mátrai szanatórium műszaki története. Népegészségügy 4: 137-143.

PAPP, B. \& SzURDOKI, E. (2018). Bryophyte flora of the forests of Vétyem and Oltárc protected areas (Zala County, W Hungary). Studia botanica hungarica 49(1): 83-96. https://doi.org/10.17110/StudBot.2018.49.1.83

PApp, B., Erzberger, P., Ódor, P., Hock, Zs., SzövÉnyi, P., Szurdoki, E. \& Tóth, Z. (2010). Updated checklist and red list of Hungarian bryophytes. Studia botanica hungarica 41: 31-59.

Söderström, L., Hagborg, A., von Konrat, M., Bartholomew-Began, S., Bell, D., Briscoe, L., Brown, E., Cargill, D.C., Costa, D.P., Crandall-Stotler, B.J., Cooper, E.D., Dauphin, G., Engel, J.J., Feldberg, K., Glenny, D., Gradstein, S.R., He, X., HeinRichs, J., Hentschel, J., Ilkiu-Borges, A.L., Katagiri, T., Konstantinova, N.A., Larraín, J., Long, D.G., Nebel, M., Pócs, T., Puche, F., Reiner-Drehwald, E., Renner, M.A.M., SassGyarmati, A., Schäfer-Verwimp, A., Moragues, J.G.S., Stotler, R.E., Sukkharak, P., Thiers, B.M., URibe, J., VáŇA, J., Villarreal, J.C., Wigginton, M., Zhang, L. \& ZhU, R.-L. (2016). World checklist of hornworts and liverworts. PhytoKeys 59: 1-828. https://doi.org/10.3897/phytokeys.59.6261

SZÚCS, P., PÉnZES-KónYA, E., HofmAnN, T. (2017). The bryophyte flora of the village of Almásfüzitő, a former industrial settlement in NW-Hungary. Cryptogamie, Bryologie 38(2): 153-170. https://doi.org/10.7872/cryb/v38.iss2.2017.153

VejmelKové, J. (2014). Bryophytes growing on trees in the Smetana Park in Olomouc (Diploma thesis). Department of Botany, Faculty of Science, Palacký University in Olomouc, 66 p. (in Czech)

Wolski, G.J., StefaniaK, A. \& Kowalkiewicz, B. (2012). Bryophytes of the experimental and teaching garden of the faculty of biology and environmental protection, University of Łódź (Poland). Ukrainian Botanical Journal 69(4): 519-529.

(submitted: 15.12.2018, accepted: 30.12 .2018 ) 


\section{APPENDIX}

\section{Site details}

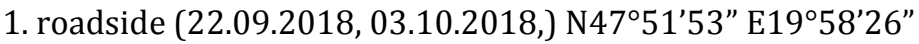

2. mown lawn (22.09.2018) N4751'53" E19 $58^{\prime} 29^{\prime \prime}$

3. embankment of road (22.09.2018, 03.10.2018) N4751'54" E1958'30"

4. roadside (03.10.2018) N4751'54" E1958'30"

5. embankment of road (22.09.2018, 03.10.2018) N4751'53" E19 58'29"

6. artifical stone wall (03.10.2018) N4751'52" E1958'30"

7. submontane beech forest (03.10.2018) N47 51'52" E19 $58^{\prime} 31^{\prime \prime}$

8. asphalt roofing felt (03.10.2018) N47 $51^{\prime} 51^{\prime \prime} \mathrm{E} 19^{\circ} 58^{\prime} 32^{\prime \prime}$

9. mown lawn (03.10.2018) N4751'51" E1958'32"

10. mown lawn and pavement (03.10.2018) N4751'51" E19 $58^{\prime} 37^{\prime \prime}$

11. woody vegetation (03.10.2018) N4751'50" E19 $58^{\prime} 26^{\prime \prime}$

12. stony embankment of road (03.10.2018) N47 $51^{\prime} 51^{\prime \prime} \mathrm{E} 19^{\circ} 58^{\prime} 27^{\prime \prime}$

13. stairs handrail (03.10.2018) N47 $51^{\prime} 51^{\prime \prime} \mathrm{E} 19^{\circ} 58^{\prime} 28^{\prime \prime}$

14. roadside, public flowerpot and andesite rock (22.09.2018) N47 $51^{\prime} 47^{\prime \prime}$ E19०58'29"

15. roadside (22.09.2018) N4751'47" E19 $58^{\prime} 31^{\prime \prime}$

16. rockery (22.09.2018, 03.10.2018) N4751'48" E19 $58^{\prime} 32^{\prime \prime}$

17. mown lawn (22.09.2018,03.10.2018) N4751'49" E1958'34"

18. roadside (03.10.2018) N4751'49" E19 $58^{\prime} 35^{\prime \prime}$

19. abandoned fountain pool (22.09.2018) N47 $51^{\circ} 48^{\prime \prime} \mathrm{E} 19^{\circ} 58^{\prime} 38^{\prime \prime}$

20. embankment and mown lawn (22.09.2018) N4751'48" E19 $58^{\prime} 39^{\prime \prime}$

21. embankment and mown lawn (22.09.2018) N4751'48" E19 58'39"

22. stony ditch (22.09.2018) N4751'49" E19 $58^{\prime} 39^{\prime \prime}$

23. stony embankment of road (03.10.2018) N4751'48" E19 $58^{\prime} 44^{\prime \prime}$

24. embankment of road (03.10.2018) N47 $51^{\prime} 50^{\prime \prime} \mathrm{E} 19^{\circ} 58^{\prime} 45^{\prime \prime}$

25. mown lawn and roadside (03.10.2018) N47 $51^{\prime} 50^{\prime \prime} \mathrm{E} 19^{\circ} 58^{\prime} 44^{\prime \prime}$

26. brook (03.10.2018) N47ㄷ1'50" E19 $58^{\prime} 52^{\prime \prime}$

27. brook (03.10.2018) N4751'52" E19 $58^{\prime} 52^{\prime \prime}$

28. roadside, construction waste (03.10.2018) N47 $51^{\prime} 52^{\prime \prime}$ E19 $58^{\prime} 52^{\prime \prime}$

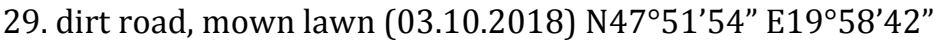

30. roadside, trees (03.10.2018) N4751'57" E19 $58^{\prime} 41^{\prime \prime}$

31. mown lawn (03.10.2018) N4751'57" E19 $58^{\prime} 41^{\prime \prime}$

32. building, artifical stone (03.10.2018) N4751'59" E1958'38"

33. mown lawn (03.10.2018) N4751'56" E19 $58^{\circ} 39^{\prime \prime}$

34. Picea plantation, stump (03.10.2018) N4751'56" E1958'39" 


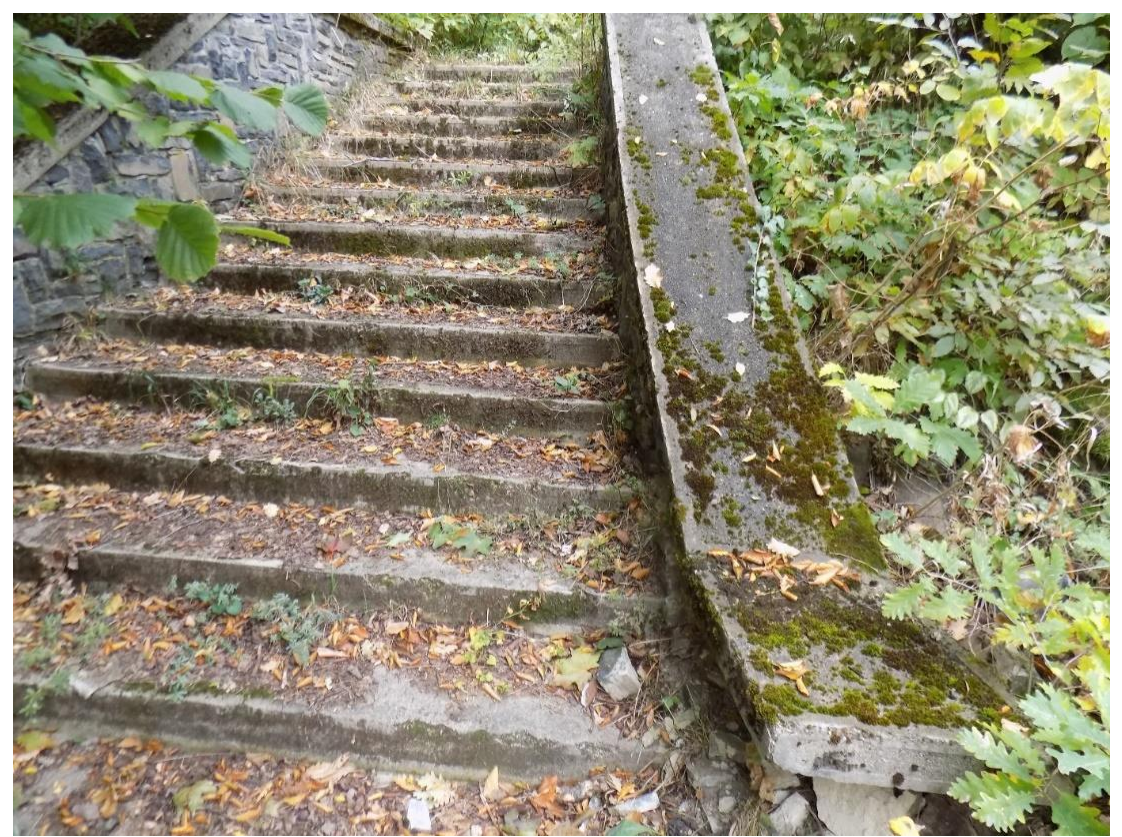

Figure 2. The occurence of Syntrichia latifolia on the stairs handrail (photo: P. Szűcs)

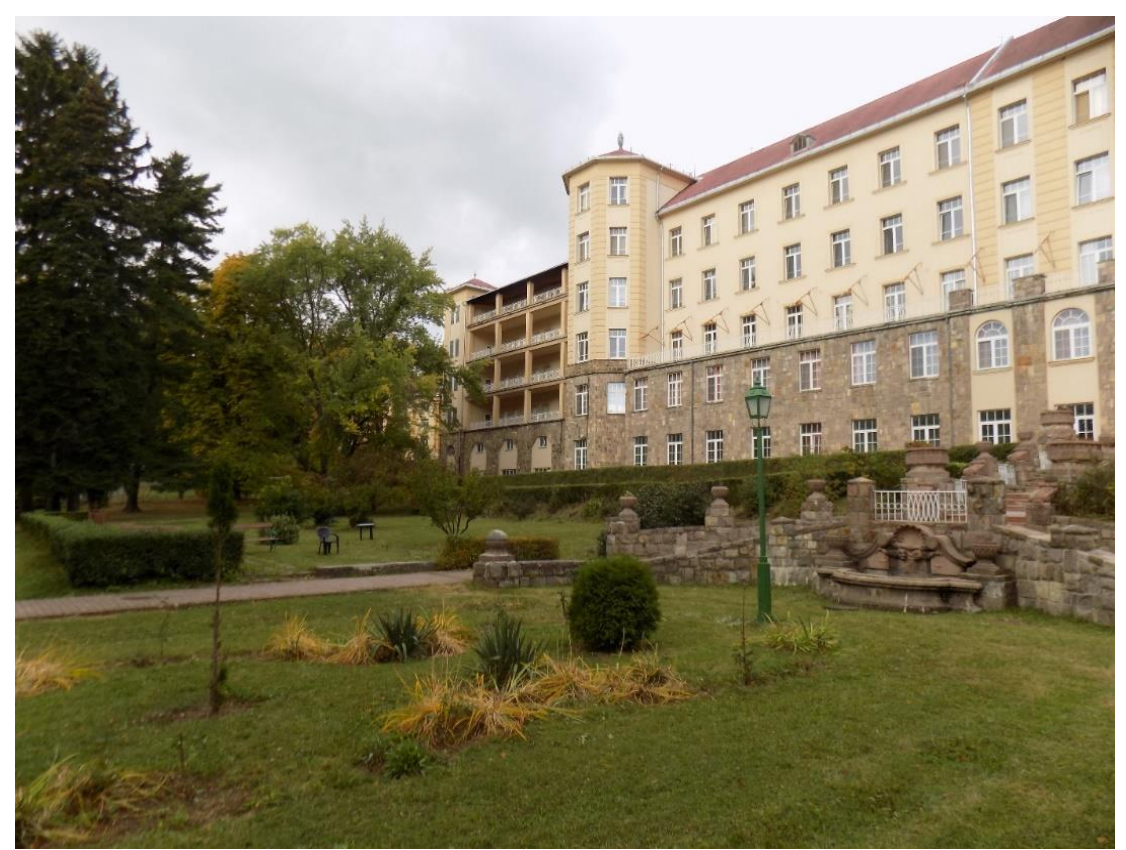

Figure 3. The mown lawn habitat of park of Hospitals Mátra (photo: P. Szűcs) 